\title{
Питання психології
}

УДК $159.942+159.947+159.98$

DOI: $10.33099 / 2617-6858-21-59-1-28-35$

Березовська Л. I. кандидат психологічних наук, дочент https://orcid.org/0000-0002-5972-7883

Сахон В. О. студентка спеціальності Психологія;

Павлик У. В. студентка спеціальності Психологія

Національний університет «Львівська політехніка».

\section{СОЦІАЛЬНО-ПСИХОЛОГІЧНІ ЧИННИКИ СХИЛЬНОСТІ ОСОБИСТОСТІ ДО УТВОРЕННЯ СПІВЗАЛЕЖНИХ СТОСУНКІВ}

У статті представлено результати теоретичного та емпіричного дослідження чинників утворення співзалежних стосунків. Проаналізовані різні підходи до визначення співзалежності та визначений деструктивний вплив міжособистісної залежності на структуру особистості. Отримані результати розщирили уявлення про зв Язок між невпевненістю в собі, емочійною опорою на інших, безпомічною поведінкою, реалізованою віктимністю та схильністю до співзалежсної поведінки.

Ключові слова: адикиія; міжособистісна залежність; співзалежність; стосунки; особистість.

Вступ.

3 кожним роком питання адиктивної та залежної поведінки стає все більш актуальним та гострим не лише для України, а й для багатьох країн по всьому світу. I якщо $з$ приводу алкогольної, тютюнової чи ігрової залежності вже, мабуть, ні в кого не виникає запитань, то феномен міжособистісної залежності все ще $\epsilon$ таємницею для значної частини населення нашої планети. Саме тому ми пропонуємо розглянути чинники схильності до утворення міжособистісної залежності, а конкретно співзалежності - підвиду міжособистісної залежності, при якому об`єктом залежності є індивід, який страждає на певний тип адиктивної поведінки (наприклад, вище згадуваний алкоголізм, геймінг тощо).

На перший погляд може здатись, що співзалежність не $\epsilon$ аж настільки поширеним явищем, однак, якщо звернути увагу на статистику, можна спостерігати, що 3 кожним роком кількість узалежнених збільшується у геометричній прогресії, а, отже, кількість співзалежних аналогічно невпинно росте. Для підтвердження варто згадати дані статистики стосовно насилля, яку оприлюднило Міністерство соціальної політики України за 2020 рік - лише за цей рік кількість звернень 3 питань насилля збільшилась на 66\%. Найбільш тривожним $\epsilon$ те, що воно відбувається, як правило, або відносно одного партнера до іншого, або батьків до дитини, тобто у тривалих стосунках. А наявність насилля у стосунках i неможливість припинити ці стосунки $\epsilon$ однією з ознак співзалежних стосунків. За таких обставин можна припускати, що найближчим часом це стане проблемою масштабів всього людства, що ймовірно фатально зашкодить нашому психічному та емоційному здоров ю.

Проблеми дослідження співзалежності почали активно розглядати ще $3 \mathrm{XX}$ століття як вітчизняні, так і зарубіжні автори (С.C. Азізов, А. Голдберг, Дж. Блок, $€$. Змановська, М.Є. Жидко, В. Міллер, М. Орзак, Р. Кауфман, Г.В. Лозова, М.М. Мателега, М.Г. Рябова, Б. Уӥльямс та інші.) і всі вони поділяють думку, що співзалежність $є$ поширеним розладом, який негативно впливає на фізичне, емоційне здоров'я людини, іï соціальний розвиток та духовний стан, тож у зв'язку з цим важливо знайти ті психологічні ланки, які беруть участь у формуванні міжособистісної співзалежності.

Метою статті виступає теоретичний та емпіричний розгляд соціальнопсихологічних схильностей особистості до утворення співзалежних стосунків.

\section{Завдання статті:}

1. Висвітлення психологічних підходів до феномену співзалежних стосунків.

2. Аналіз соціально-психологічних чинників, що впливають на утворення співзалежних стосунків.

Методи дослідження.

Для розв'язання поставлених у статті завдань використано комплекс методів: оглядово-аналітичний (огляд та аналіз сучасної зарубіжної та вітчизняної літератури; оглядово-порівняльний; теоретичний (узагальнення психологічної літератури щодо співзалежності 


\section{Питання психології}

особистості). Емпіричне дослідження соціально-психологічних

чинників

схильності до утворення співзалежних стосунків здійснено за такими методичними засобами, як: авторська анкета, опитувальник міжособистісної залежності (Р. Гіршфільд), методика «Схильність до віктимної поведінки» (О.О. Андроннікова), опитувальник «Рольові позиції в міжособистісних відносинах» (Е. Берн). Опис здійснено на основі використання методів математичної статистики: метод порівняння незалежних груп (критерій Манна-Уітні) та кореляційний аналіз (критерій r-Пірсона) [1].

\section{співзалежності.}

Огляд сучасних досліджень феномену

Міжособистісна залежність розуміється як залежність від іншої людини. Найчастіше термін співзалежність вживається відносно до родичів i близьких алкоголіків, наркоманів та інших людей з якими-небудь соціальними вадами або залежностями, однак далеко не обмежується ними. Співзалежною можна вважати будь-яку людину, яка живе у неблагополучній родині 3 нездоровими правилами, що сприяють співзалежним стосункам. Стан співзалежності характеризується емоційною, соціальною, а іноді і фізичною залежністю від іншої людини, а 3 плином часу набуває патологічних ознак, що впливає на співзалежного у всіх його взаємовідносинах [3, с. 154].

Більшість фахівців в сфері залежностей розглядають співзалежність як індивідуальну або сімейну проблему, деякі як «системну» проблему, однак, лише одиниці починають розглядати ii як проблему всього нашого суспільства. Енн Уїлсон Скеф в своїх роботах виділяе дві системи, які, на iï думку, вступають в конфлікт: Біла Чоловіча, або Система, для якої характерна залежність, і Рятувальна жіноча, або Система життєвого процесу. В своій роботі «Чаша і билинка» Райен Айслер проводить детальний аналіз протиріч та проблем, які породжує кожна 3 моделей. Дослідження Р. Айслер охоплюють взаємостосунки статей протягом всієї історії людства, зіставляє факти, взяті зі сфер мистецтва, археології, релігії, соціології, історії та інших наук, щоб створити нову історію про наші культурні витоки.
Згідно Р. Айслер, домінаторне суспільство культивує якості, які ми традиційно асоціюємо 3 мужністю, цінує готовність віддати своє життя і деструктивні діï, такі як завоювання території і війна. Ця соціальна структура, побудована на нерівності, як правило, ставить одну частину суспільства над іншою. Незважаючи на те, що культурні цінності цих общин можна назвати зараз «важкими» або більш «чоловічими», домінаторні суспільства можуть бути як матріархальними, так i патріархальними. Група людей, що стоять вище, утримує в своїх руках владу, бере на себе ризик i отримує всі винагороди, залишаючи нижчу групу позбавленою влади i часто бідною. Замість взаємного співробітництва люди пов 'язані конкуренцією, утворюють ієрархію, яка в підсумку повинна підтримуватися силою або загрозою сили. Це створює атмосферу недовіри і роз єднання. У цій перспективі ми почали розуміти, що причини співзалежності сягають своїм корінням у глибину нашої соціальної структури. Будьяка культура, яка ставить одну стать, одну релігію, одну расу вищу за іншу створює суспільство, готове бути співзалежним [4, с. 37-40].

Багатьох людей та науковців бентежить «епідемія співзалежності», яка 3 кожним роком все більше поширюється вже сучасним суспільством у всьому світі, оскільки людство начебто розвивається, а патерни поведінки залишаються ті ж, що і у наших предків. Однак, наука не стоїть на місці, тому на сьогодні існує кілька припущень причин виникнення такої поведінки.

Психологи давно почали досліджувати джерела емоційних травм у дорослих і дітей, а також шукати нові шляхи розкриття людських можливостей. Досліджуючи ці два процеси одночасно, психологи стали розрізняти моделі взаємин, в яких простежувався зв`язок між вихованням дитини і рівнем іiї потенціалу, тобто того, чого вона може досягти. Стало зрозуміло, що способи, за допомогою яких наше культурне середовище виховує своїх дітей, заважають розвитку їх людських здібностей.

Для того щоб психологічне народження особистості успішно завершилося до віку двох-трьох років, необхідно, щоб обоє батьків виступали в якості буфера між 


\section{Питання психології}

дитиною і один одним протягом процесу відділення. Батьківська підтримка допомагає дитині завершити процес диференціації: вона навчається відрізняти себе від інших і починає мислити, визнаючи як позитивні, так і негативні якості і в собі, і в інших.

В результаті впливу нашої домінаторної культури батьки роблять цілий ряд вчинків, які можуть зашкодити відділенню i диференціації. Наприклад, батько може навчати дівчаток того, що їм потрібно робити, щоб чоловік опікав їх, або заохочувати хлопчиків недооцінювати або занадто переоцінювати жінок. Крім того, батьки часто бояться опинитися між дружиною і дитиною під час «боротьби воль» і йдуть в роботу або інші заняття i таким чином залишаються не в курсі справ. Деякі батьки так бояться цього, що вважають за краще повністю припинити відносини, ніж бути втягнутим в боротьбу за владу. Залежна мати теж може відчувати побоювання, що батько дитини спробує «вбити клин» між нею та іiі дитиною, і тому може зробити спробу вигнати слабовільного батька 3 дому в цей період. Тоді матері i дитині доведеться самим дбати про себе, і в результаті ймовірність завершення психологічного народження зведеться практично до нуля.

Для успішної сепарації дітям необхідна присутність батька, або матері, або обох пов'язаних між собою дбайливих людей, які досить впевнені в собі, щоб ризикнути перебувати деякий час в центрі боротьби. Вони повинні вміти проникати в почуття один одного і в почуття дитини, а також бути в змозі проявляти ій всю свою ніжність протягом цих довгих місяців. Без всього цього діти не зможуть відокремитися емоційно i розглядати своїх батьків як окремі об`єкти 3 хорошими і поганими якостями, а також не зможуть бачити себе як окремий об єкт, що володіє як хорошими, так і поганими якостями.

Коли діти позбавлені достатньої сталості об єкта і розглядають свою матір або батька як «поганого батька», вони починають вважати себе «поганою дитиною». Тут повністю відсутня будь-яка диференціація. Ніхто ніколи не доб ється відособленості або автономії, вважаючи іншого поганим або неправим. Багато хто намагається відокремитися від своїх батьків в підлітковому віці або пізніше, вже дорослими, використовуючи такий підхід. Відособленість з являється тільки тоді, коли діти бачать як хороше, так і погане в своїх батьках, а також і в самому собі («У тебе все в порядку, у мене теж»).

Якщо існує достатня сталість об'єкта, то дитина засвоїть думку про те, що жодна людська істота не $\epsilon$ ні ідеально хорошою, ні абсолютно поганою. Вона зможе примиритися 3 недосконалістю i стійко триматися за свої «чесноти» навіть тоді, коли іï найбільше мучать власні життєві негаразди та життєві слабкості. Вона зможе дозволити собі ставитися до інших людей зі змішаними почуттями і розглядати їх як рідних їй людських істот зі своїми недоліками і перевагами. Вона зуміє робити те ж саме і відносно себе, і ій не потрібно буде вивертати назовні ті частини себе, які ій не дуже подобаються. Вона зможе брати на себе відповідальність за свою конфліктну поведінку і їй не потрібно буде проектувати на інших свої почуття і думки.

Якщо у дитини не розвинута достатня сталість об єкта, то ймовірно вона не зможе владнати суперечності між єдністю i відокремленістю, тож зазнає невдачі при повторних спробах завершити своє психологічне народження. Можливо, вона буде регулювати своє життя, розділяючи свій досвід на дві несумісні частини - це все погано, а це все добре. У іï мисленні в основному будуть переважати порівняння. Себе вона будете вважати кращою або гіршою, ніж інші. У взаєминах вона буде відчувати себе «вище» або «нижче», ніж інша людина і ій буде важко вважати себе рівною кому б то не було. Дитина буде відчувати, що керує ситуацією тільки тоді, коли маніпулюватиме іншою людиною, роблячи ii своєю опорою. Така «опора» повинна робити все, щоб підтримувати в такій дитині (навіть, якщо це вже доросла особистість) віру в іiі досконалість $[4$, с. 6669].

Сьогодні існує два основних підходи до розуміння i вивчення феномену співзалежності, а саме: медичний та еволюційний. Автори та прихильники медичного підходу (О.А. Шорохова, М. Бітті, В.Д. Москаленко) стверджують, що співзалежність можна розглядати як стійке, прогресуюче захворювання, яке передається генетично та не піддається лікуванню. 3 точки зору еволюційної теорії (Б. Уайнхолд, 


\section{Питання психології}

Дж. Уайнхолд), співзалежність $є$ психологічним розладом, спричиненим порушенням встановлення психологічної автономії дитини у ранньому віці.

3 точки зору традиційного підходу (Р. Хемфелт, Ф. Мінірт, П. Майєр) виокремлюють п'ять стадій розвитку співзалежності. Ці стадії повторюються за рухом спіралі, по завершенню останньої стадії все знову розпочинається спочатку. 3 кожним разом цикл проходить все швидше, що згубно впливає на психічний стан людини [2, с. 136-138].

Міжособистісну залежність можна визначити за такими ознаками, як: нездатність самостійно приймати рішення без допомоги інших людей; готовність людини довірити прийняття важливих для неї рішень іншим людям; згода з іншими від страху бути знехтуваним (навіть якщо інші помиляються) труднощі у самостійному виконанні справ; готовність індивіда принижуватись та виконувати неприємну роботу з метою заслужити похвалу, повагу, увагу та любов оточуючих; страх самотності та постійні намагання ііі уникнути будь-якою ціною; відчуття безпомічності та спустошення при втраті зв 'язку з близькою людиною; легка вразливість, страх критики, глибокі переживання 3 цього приводу. Для ствердження наявності залежної поведінки даного типу, необхідним $\epsilon$ прояв щонайменше п'яти ознак [3, с.149].

Співзалежна людина часто відчуває себе жертвою через небажання партнера допомогти їй в створенні ідеальних взаємин, в яких всі їхні потреби задовольняються (насправді, лише одного 3 них). В результаті обидва відчувають, що повинні знайти спосіб стати жертвою в цих взаєминах i задовольняти свої потреби, не просячи про це. Розвиваючи працю Берна щодо ролей у грі, Стів Карпман визначив, що кожна п'єса потребує жертви. А щоб стати жертвою, людині потрібен або рятівник, або переслідувач. Щоб п'єса розвивалася, люди міняються ролями і навіть залучають інших осіб, формуючи драматичний трикутник транзакцій. Перший акт цієї драми зазвичай починається зі взаємодії між переслідувачем i жертвою. Другий акт починається, коли приходить рятувальник, щоб виручити жертву. У третьому акті рятувальник нападає на переслідувача. Потім починається нова драма. Переслідувач стає жертвою, рятувальник - переслідувачем, а жертва займає положення рятувальника. Ці драми рухаються як карусель, де гравці весь час змінюються позиціями. Змагання за стан жертви підтримує рух каруселі. Неможливо не помітити, що в «драматичному трикутнику» існують взаємини між переслідувачем і жертвою, між жертвою і рятувальником. Однак між рятувальником i переслідувачем взаємини відсутні. Ця відсутність відносин є критичною, оскільки, якби рятувальник і переслідувач припинили спілкування, гра закінчилася б [4, с. 70-71].

\section{Основні результати дослідження соціально-психологічних чинників схильності особистості до співзалежності.}

У дослідженні взяли участь 53 респонденти чоловічої та жіночої статі різних вікових категорій. Згідно результатів анкети $44,4 \%$ опитуваних на даний момент не мають пари, 27,8\% перебувають у стосунках, 18,5\% - одружені, у окремих все складно, розлучені, вдівці та $є$ у вільних стосунках. $\quad 75,9 \% \quad$ респондентів виховувались у родині з іншими дітьми (братами/сестрами), в той час як $24,1 \%$ були єдиною дитиною у батьків. 59,3\% опитуваних проживає з батьками, 18,5\% - 3 власною сім єю (чоловіком/дружиною та дітьми, за наявності), 11,1\% - самі, 5,6\% - 3 партнером/партнеркою та по 1,9\% припадає на проживання 3 друзями та іншими родичами (окрім батьків). 42,6\% ніколи не піддавалися психологічному/фізичному чи економічному насиллю у стосунках, $27,8 \%$ мали у своєму житті одиничний епізод насилля, 25,9\% піддавались насиллю протягом тривалого часу, а $3,7 \%$ утримались від $\quad$ відповіді. $53,7 \% \quad$ респондентів піддавались насиллю 45,7\% відчували це у стосунках з батьками, 22,9\% у стосунках 3 партнерами, окремі у стосунках з друзями, у стосунках 3 партнером та батьками одночасно, у стосунках 3 батьком, у стосунках з братом, а також у школі та на роботі. Серед опитаних нами людей, які піддавались насиллю, 69,9\% продовжили ці стосунки, 30,1\% завершили ці стосунки одразу або через короткий проміжок часу після інциденту (змінили місце праці, перервали стосунки тощо). 64,8\% респондентів не мали досвіду стосунків 3 узалежненими людьми (3 алкогольною/ наркотичною/ ігровою/ комп'ютерною/ сексуальною та ін. залежністю), 35,2\%мали, 


\section{Питання психології}

$36,4 \%$ перебували у співзалежних стосунках 3 батьками, $27,3 \% \quad-\quad 3$ партнером/партнеркою, $18,2 \%$ - 3 друзями, 9,1\% - з чоловіком/дружиною.

Для виділення досліджуваних із співзалежністю ми скористалися шкалою «досвід стосунків з узалежненими людьми (з алкогольною / наркотичною / азартною / комп'ютерною / сексуальною та ін. залежністю)». Ствердна відповідь дозволяє нам розглядати цих респондентів як ймовірно співзалежних.

Аналіз порівняння групи співзалених та тих, хто не перебуває у таких стосунках 3 використанням методу порівняння незалежних груп (критерій Манна-Уітні) показав, що є відмінності на статистичному рівні. Вони проявляються за такими шкалами, як: міжособистісні стосунки $(\mathrm{r}=$ $0,023)$, емоційна опора на інших $(r=0,045)$ та невпевненість у собі $(\mathrm{r}=0,041)$. Отже, ті хто має досвід співзалежних стосунків схильні залежних стосунків у міжособистісній взаємодії, до емоційної опори на інших та невпевнені у собі.

Для визначення взаємозв'язків між проявом співзалежних стосунків та соціально-психологічних чинників було застосовано кореляційний аналіз (критерій rПірсона). Для зручності та чіткішого розуміння отримані результати будуть представлені у плеяді (рис. 1).

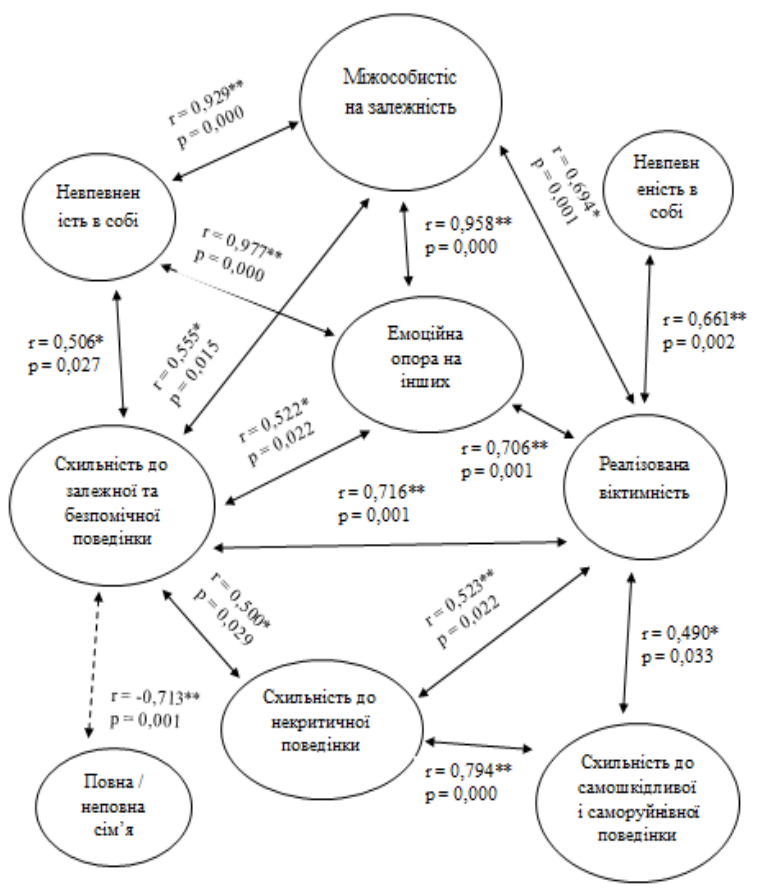

Рис. 1. Кореляційна плеяда міжособистісної залежності
Кореляційний аналіз показав, що міжособистісна залежність (співзалежність) має сильний прямий кореляційний взаємозв'язок $з$ невпевненістю в собі $(\mathrm{r}=$ $0,929$ при $\mathrm{p}=0)$ та емоційною опорою на інших $(r=0,958$ при $\mathrm{p}=0)$, тобто чим більша невпевненість людини в собі, та чим більше вона прагне емоційно опиратись на когось, тим вищим стає іiі рівень міжособистісної залежності, і навпаки. У свою чергу емоційна опора сильно корелює 3 невпевненістю у собі $(\mathrm{r}=0,977$ при $\mathrm{p}=0)$, тож можна стверджувати, що з підвищенням першого, буде рости і друге.

Отже, ті хто має досвід співзалежних стосунків схильні до залежних стосунків у міжособистісній взаємодії, до емоційної опори на інших та невпевнені у собі.

Суттєві та прямі взаємовпливи міжособистісної залежності ( $\mathrm{r}=0,694$ при $\mathrm{p}$ $=0,001)$, емоційної опори на інших $(\mathrm{r}=0,706$ при $\mathrm{p}=0,001)$ та невпевненості в собі $(\mathrm{r}=$ $0,661$ при $\mathrm{p}=0,002)$ були виявлені 3 реалізованою віктимністю. Високий рівень реалізованої віктимності може означати те, що людина часто потрапляє в неприємні ситуації, які іноді можуть бути навіть небезпечними для іiі здоров'я та життя загалом. Таким чином невпевнена в собі особистість, яка має потребу в емоційній опорі на інших та високий рівень міжособистісної залежності буде більш схильна до реалізації віктимної поведінки, що в свою чергу схилятиме іï до агресивних, необдуманих спонтанних дій, які нестимуть в собі загрозу. I навпаки, прагнення до небезпечних дій та ситуацій впливатиме на міжособистісну залежність, схилятиме до пошуку надійної опори та збільшуватиме невпевненість у собі.

Отже, реалізована віктимність, яка безпосередньо впливатиме на міжособистісну залежність, емоційну опору на інших та невпевненість у собі є одним 3 чинників, які вливають на схильність до співзалежної поведінки.

Реалізованою віктимністю та схильністю до залежної та безпомічної поведінки $(r=0,716$ при $\mathrm{p}=0,001)$ пояснює постійне залучення людини до кризових ситуацій з метою отримання співчуття та підтримки з боку партнера/партнерки, сім’ї чи оточення загалом. Схильність до залежної та безпомічної поведінки можна розглядати як небажання робити щось 


\section{Питання психології}

самотужки, без допомоги інших через помірний прямий взаємозв'язок 3 емоційною опорою на інших ( $\mathrm{r}=0,522$ при $\mathrm{p}$ $=0,022) ;$ або 3 точки зору низької самооцінки, про що свідчить помірний прямий взаємовплив 3 невпевненістю в собі $(\mathrm{r}=0,506$ при $\mathrm{p}=0,027)$. Рольова позиція жертви, боязкість, конформність та тенденція піддаватись навіюванню, як характеристики особистості схильної до залежної та безпомічної поведінки, пояснюють помірний кореляційний зв'язок 3 міжособистісною залежністю $(\mathrm{r}=0,555$ при $\mathrm{p}=0,015)$. Цікавим моментом у процесі аналізу було виявлення суттєвого оберненого зв'язку між схильністю до залежної та безпомічної поведінки та досвідом зростання людини у повній або неповній сім'ї $(\mathrm{r}=-0,713$ при $\mathrm{p}=0,001)$. Даний зворотній зв'язок свідчить про вплив наявності обох або одного з батьків на формування залежності через розвиток безпорадної поведінки. Тобто, чим довше людина прожила у неповній сім'ї, тим сильніше у неї розвиватимуться безпорадність, поступливість та залежність.

Ще два помірних прямих кореляційних зв'язка було виявлено між схильністю до некритичної поведінки і схильністю до залежної та безпомічної поведінки $(\mathrm{r}=0,500$ при $\mathrm{p}=0,029)$; схильністю до некритичної поведінки та реалізованою віктимністю ( $\mathrm{r}=$ $0,523$ при $\mathrm{p}=0,022)$, де перший взаємовплив розкриває особу з некритичною поведінкою як надмірно довірливу людину, що немає міцних моральних засад, але має тенденцію виправдовувати негативну поведінку інших, 3 метою залишатись безпорадною жертвою у співзалежних стосунках. Тобто з високим рівнем некритичної поведінки, ростимуть безпомічність та залежність. Другий взаємовплив свідчить про те, що необачність і легковажність особистості, іiі невміння правильно оцінювати життєві ситуації та нерозбірливість в знайомствах (як характеристики некритичної поведінки) будуть підвищувати ймовірність потрапляння у небезпечні та загрозливі ситуації, тим самим реалізовуючи віктимну поведінку. I навпаки, чим більше людина наражатиме себе на небезпеку, тим більш некритичною буде іiї поведінка. Схильність до некритичної поведінки демонструє також суттєвий прямий взаємозв'язок зі схильністю до самоушкоджуючої та саморуйнівної поведінки ( $\mathrm{r}=0,794$ при $\mathrm{p}=$ $0)$, тобто чим сильніше в особи проявляється тенденція до некритичного мислення та поведінки, тим більше вона буде схильна до саморуйнації. В цьому випадку вона може проявляти свою жертовність через провокацію ситуації віктимності, або завдавати шкоди самій собі. 3 цього випливає ще один помірний прямий взаємовплив схильності до самоушкоджуючої та саморуйнівної поведінки 3 реалізованою віктимністю ( $\mathrm{r}=$ $0,490$ при $\mathrm{p}=0,033)$, який дозволяє стверджувати що чим більше людина буде вдаватись до самоушкоджуючої поведінки, завдаючи собі шкоди прямо чи опосередковано, тим більше проявлятиметься іiі реалізована віктимність, яка несе в собі загрозу ії життю та здоров’ю, і навпаки.

Отже, ще одними чинниками впливу на схильність до співзалежності $€$ наступні фактори: схильністю до залежної та безпомічної поведінки, досвідом зростання людини у повній або неповній сім'ї, схильність до некритичної поведінки і схильність до самоушкоджуючої та саморуйнівної поведінки.

Ми припускали, що Его-стани $\epsilon$ чинником утворення співзалежних стосунків, проте не виявили їхнього зв'язку з виникненням співзалежності.

Отже, можна виокремити дві групи чинників, що визначають схильність особистості до утворення співзалежних стосунків: соціальні та психологічні. До соціальних чинників ми відносимо досвід стосунків 3 узалежненими людьми (проживання та виховання у родині 3 узалежненим, дружба, романтичні стосунки 3 партнером/партнеркою, що страждає на залежність), а також досвід зростання людини у повній або неповній сім “̈. До психологічних чинників належать невпевненість в собі, емоційна опора на інших, реалізована віктимність, схильність до залежної, безпомічної, некритичної, самоушкоджуючої і саморуйнівної поведінки.

\section{Висновки та перспективи подальших досліджень.}

Визначено, що у досліджуваних рівень міжособистісної залежності безпосередньо залежить від невпевненості в собі, емоційної опори на інших (високий рівень зв'язку), 


\section{Питання психології}

безпомічної поведінки (суттєвий рівень зв'язку), реалізованої віктимності та схильності до залежної поведінки (помірний рівень зв'язку). Також простежуються проміжні зв'язки: прямі з помірним рівнем зв'язку (схильність до некритичної поведінки, схильність до самоушкоджуючої та саморуйнівної поведінки), зворотній 3 суттєвим рівнем зв'язку (зростання у повній або неповній сім’ї).

До соціальних чинників співзалежності відносяться досвід стосунків 3 узалежненими людьми (проживання та виховання у родині з узалежненим, дружба, романтичні стосунки 3 партнером/партнеркою, що страждає на залежність), а також досвід зростання людини у повній або неповній сім ї. До психологічних чинників належать невпевненість в собі, емоційна опора на інших, реалізована віктимність, схильність до залежної, безпомічної, некритичної, самоушкоджуючої і саморуйнівної поведінки.

Оскільки тема дослідження є надзвичайно широка і охопити всі фактори неможливо, тому чітко і точно сказати, що $\epsilon$ провокуючими чинниками, a що $\epsilon$ результатом складно. Необхідне проведення додаткових досліджень для того, щоб могти більш детально та впевнено говорити про конкретний вплив тих чи інших чинників на схильність до виникнення міжособистісної залежності i утворення співзалежних стосунків. Що і буде перспективою наших подальших досліджень.

\section{Список використаних джерел}

1. Климчук В. О. Математичні методи у психології. Навчальний посібник для студентів психологічних спеціальностей. - К.: Освіта України. - 2009. - 288 с..

2. Мілушина М. О. Специфіка динамічних проявів розвитку співзалежності / М. О. Мілушина // Актуальні проблеми психології. - 2014. - Т. 7: Екологічна психологія, вип. 37. - С. 135

3. Психологічні особливості залежності як девіантної поведінки особистості / М. М. Мателега, С. С. Азізов // Психологічні науки: проблеми і здобутки. - 2015. - Вип. 7. - С. 146-160.

4. Уайнхолд Б. Освобождение от созависимости / Б.Уайнхолд, ДжУайнхолд; перевод с английского А.Г. Чеславской. - М. : Независимая фирма «Класс», 2002. - 224 с

\section{References}

1. Klymchuk V. O. Matematychni metody u psykholohii. [Mathematical methods in psychology] Navchalnyi posibnyk dlia studentiv psykholohichnykh spetsialnostei. - K.: Osvita Ukrainy. - 2009. - 288 s. (in Ukrainian)

2. Milushyna M. O. Spetsyfika dynamichnykh proiaviv rozvytku spivzalezhnosti [The specifics of the dynamic manifestations of the development of interdependence] / M. O. Milushyna // Aktualni problemy psykholohii. - 2014. - T. 7: Ekolohichna psykholohiia, vyp. 37. - S. 135 (in Ukrainian)

3. Psykholohichni osoblyvosti zalezhnosti yak deviantnoi povedinky osobystosti [Psychological features of addiction as a deviant behavior of the individual] / M. M. Mateleha, S. S. Azizov // Psykholohichni nauky: problemy i zdobutky. - 2015. - Vyp. 7. - S. 146-160 (in Ukrainian)

4. Uaynkhold B. Osvobozhdenie ot sozavisimosti [Liberation from codependency] / B.Uaynkhold, DzhUaynkhold; perevod s angliyskogo A.G. Cheslavskoy. - M. : Nezavisimaya firma «Klass», 2002. - 224 s. (in Russia)

\section{Резюме}

Березовская Л. И. кандидат психологических наук, доцент

Сахон В. О. студентка специильности Психология

Павлик У. В. студентка специальности Психология

Наииональныгй университет «Львівська політехніка».

\section{СОЦИАЛЬНО-ПСИХОЛОГИЧЕСКИЕ ФАКТОРЫ СКЛОННОСТИ ЛИЧНОСТИ К} ФОРМИРОВАНИЮ СОЗАВИСИМЫХ ОТНОШЕНИЙ

В статье представлены результаты теоретического и эмпирического исследования факторов образования созависимых отношений. Проанализированы различные подходы $\kappa$ определению созависимости и определенный деструктивное влияние межличностной зависимости на структуру личности. Полученные результаты расширили представление о связи между неуверенностью в себе, эмоииональной опорой на других, беспомощной поведением, реализованной виктимность и склонностью к созависимых поведения.

Ключевые слова: аддикция; мељсличностная зависимость; созависимость; отношения; личность. 


\section{Питання психології}

\section{Summary}

Berezovska L. I. Candidate of Psychological Sciences, Associate Professor;

Sakhon V. O. Psychology specialty student;

Pavlik $\boldsymbol{U}$. V. Psychology specialty student

Lviv Polytechnic National University.

\section{SOCIO-PSYCHOLOGICAL FACTORS OF PERSONALITY PREDISPOSITION TO FORM INTERDEPENDENT RELATIONSHIPS}

\section{Introduction.}

The article presents the theoretical and empirical research of socio-psychological factors' influence on forming a person's predisposition to interdependence.

Every year the number of victims of various forms of addictions is constantly increasing, and, consequently, the number of interdependent people is growing proportionally. Interpersonal dependence may seem insignificant in its prevalence and consequences compared to other addictions, such as alcoholism, drug addiction, etc. Still, if we look at the statistics, it becomes clear that this is not the case.

Purpose.

The purpose of the article is to highlight the socio-psychological factors of personality predisposition to form interdependent relationships.

\section{Methods.}

Theoretical (analysis of the literature, theoretical data generalization) and empirical (instrumental methods) research methods are used.

\section{Originality.}

The phenomenon of "interdependence" is related not only to the interpersonal sphere but also directly to the individual, negatively affecting all aspects of human life. The experience of such relationships destroys a person's physical and psychological health and is also an obstacle to the development, success, and creation of happy and harmonious relationships.

Interdependency is seen as a socially widespread phenomenon, which is the leading risk factor for forming dependent behavior. It also has a negative impact not only on an individual and his life but also on society.

The most significant factors influencing the formation of personality interdependence are identified: these include addiction and helpless behavior, emotional dependence on others, self-doubt, and victimhood. Factors such as uncritically, self-harm, self-destructive behavior, and human growth experience in a complete or incomplete family also have a significant indirect effect.

\section{Conclusion.}

There are prospects for further studies in conducting additional research to talk in more detail and confidently about the specific impact of individual factors on the predisposition to interpersonal dependence and the formation of interdependent relationships.

Key words: addiction; interpersonal dependence; codependency; relations; personality.

Автори заявляють про відсутність конфлікту інтересів.

Recelved/Поступила: 25.02. 21. 